\title{
遠心圧縮機の羽根なしディフューザで発生する旋回失速の非定常挙動と構造
}

\author{
藤澤 信道*1，三井田 弘 ${ }^{* 2}$ ，田島 健太 ${ }^{* 3}$ ，太田 有 ${ }^{* 4}$
}

\section{Unsteady behavior and mechanism of a rotating stall in a centrifugal compressor with vaneless diffuser}

\author{
Nobumichi FUJISAWA ${ }^{* 1}$, Hiroshi MIIDA ${ }^{* 2}$, \\ Kenta TAJIMA $^{* 3}$ and Yutaka OHTA ${ }^{* 4}$ \\ ${ }^{*} 1,{ }_{2},{ }^{3},{ }^{*}{ }_{4}$ Waseda Univ., Dept. of Applied Mechanics and Aerospace Engineering \\ 3-4-1 Okubo, Shinjuku-ku, Tokyo 169-8555, Japan
}

Received: 11 October 2020; Revised: 3 December 2020; Accepted: 15 January 2021

\begin{abstract}
Unsteady diffuser stall behavior in a centrifugal compressor with a vaneless diffuser was investigated by experimental and computational analyses. The diffuser stall generated as the mass flow rate decreased. The diffuser stall cell rotated at 25-30\% of the impeller rotational speed, with diffuser stall fluctuations observed at $180^{\circ}$ from the cutoff. The diffuser stall fluctuation magnitude gradually increased near the cutoff. Based on diffuser inlet velocity measurements, the diffuser stall fluctuations generated near both the shroud and hub sides, and the diffuser stall appeared at $180^{\circ}$ and $240^{\circ}$ from the cutoff. According to the CFD analysis, the mass flow fluctuations at the diffuser exit showed a low mass flow region, rotating at approximately $25 \%$ of the impeller rotational speed. They began at $180^{\circ}$ from the cutoff and developed as this region approached the cutoff. Therefore, the diffuser stall could be simulated by CFD analysis. First, the diffuser stall cell originated at $180^{\circ}$ from the cutoff by interaction with boundary separation and impeller discharge vortex. Then, the diffuser stall cell further developed by boundary separation accumulation and the induced low velocity area, located at the stall cell center. The low velocity region formed a blockage across the diffuser passage span. The diffuser stall cell expanded in the impeller rotational direction due to boundary separation caused by a positive flow angle. Finally, the diffuser stall cell vanished when it passed the cutoff, because mass flow recovery occurred.
\end{abstract}

Keywords : Centrifugal compressor, Vaneless diffuser, Rotating stall, CFD, DES

\section{1. 緒言}

ターボ機械のひとつである遠心圧縮機は，化学プラントでの気体の圧送や内燃機関への過給など，工業用途に おいて重要な役割を担っており, 高い安定性や効率性が求められる. しかし, 圧縮機は部分流量運転時において, サージや旋回失速といった非定常現象が発生することで効率の低下だけでなく, 機器や配管系の破損を招く危険 性がある. サージの予兆現象として発生する旋回失速の制御・離脱技術は非常に重要であり，旋回失速の発生機 構および非定常的な渦構造の解明が進められている。しかし，遠心圧縮機に発生する非定常現象は，渦型室の非 軸対称性や, 羽根車流路間の流体に働く慣性力により内部流れ場が複雑となっているため, 失速の非定常的な流 動構造を詳細に解明した研究報告は少ないのが現状である.

幅広い流量域において運転される遠心圧縮機において，羽根なしディフューザが採用されることが多い，その ため, 羽根なしディフューザで発生する旋回失速の研究報告がいくつかなされている．初期の研究として，羽根 なしディフューザで発生する旋回失速の初生と逆流との関連を調査した Senoo らによる報告が挙げられる(Senoo

No.20-00364 [DOI:10.1299/transjsme.20-00364], J-STAGE Advance Publication date : 26 January, 2021

${ }^{* 1}$ 正員, 早稲田大学 基幹理工学部 機械科学・航空宇宙学科（†169-8555 東京都新宿区大久保 3-4-1）

*2 学生員, 早稲田大学大学院 基幹理工学研究科

*3 早稲田大学大学院 基幹理工学研究科

*4 正員, フェロー, 早稲田大学 基幹理工学部 機械科学・航空宇宙学科

E-mail of corresponding author: yutaka@waseda.jp 
et al., 1977, Senoo and Kinoshita, 1978). Senoo らは羽根なしディフューザを採用した遠心送風機を対象に実験的お よび理論的に内部流動を調查し，旋回失速の初生基準(臨界流れ角)を提唱した．辻本らは簡易な二次元線形解析 を用いて，ディフューザ旋回失速の発生条件やその伝ぱ速度を求めた(辻本他，1994). また近年，計算機の発達 とともに数值解析手法が向上し，試験による詳細調査と合わせて，旋回失速の発生機構を明らかにする報告がな されている. Ohuchida らはPIV 計測により, ディフューザ失速発生時の境界層の剥離の様相と伝ば機構を明らか にした(Ohuchida et al., 2013). また, Bianchini らは試験によりディフューザ失速からサージに陥る過程を調査して いる(Bianchini et al., 2015). 数值解析を用いた報告例として, Yamada らはサージ点近傍における非定常 DES 解析 を行い, ディフューザ内部流れを明らかにした(Yamada et al., 2017). その結果，サージ点近傍では渦型室側から の逆流がディフューザ流路内でブロッケージとなり，境界層剥離が成長することで失速セルが形成されることを 示した. また, Dehner らはディフューザ失速の初生からサージに陥るまでの過程を数值解析により明らかにして いる(Dehner and Selamet, 2019). 数值解析により, 複数の小さな失速セルを起点として, 流量の低下に伴い舌部近 傍からの逆流の拡大により失速セルが拡大寸る様子を可視化している．このように，ディフューザ失速の発生機 構には，境界層の剥離や渦型室の非軸対称性の形状に起因寸る圧力分布などが密接に関わりあっていることがわ かる. しかし，羽根なしディフューザで発生する旋回失速の非定常挙動やその旋回機構を，境界層剥離と渦型室 の形状に起因する非軸対称な流れ場と関連付けて, 明らかにした例は少ない.

そこで本研究では, 羽根付ディフューザで発生する旋回失速の調查で開発した数值解析コードや得られた知見 (Fujisawa and Ohta, 2017, Fujisawa et al., 2019)を用いて, 羽根なしディフューザを有する遠心圧縮機における旋回失 速の非定常的な洞構造およびその旋回機構を解明することを目的とし，試験および数值解析を実施した．特に， 羽根なしディフューザ部で発生する旋回失速に着目し, 失速の非定常挙動や旋回構造について調査を行った. 部 分流量運転時に発生する旋回失速の調査のために, 高感度圧力センサを用いた圧力の多点同時計測および熱線流 速計を用いたディフューザ流路間の流速変動の計測を行った. また, ディフューザ失速セル内部の詳細な渦構造 を調査するために, ディフューザ流路流れを油膜法により可視化し，圧縮機内部流れ場の非定常 Detached Eddy Simulation(DES)解析を行った.

\section{2. 主な記号と定義}

$B \quad$ :通路幅 $[\mathrm{m}]$

$D$ :直径 $[\mathrm{m}]$

$N$ :羽根車回転数 $\left[\mathrm{min}^{-1}\right]$

$P \quad$ : : 静圧 $[\mathrm{Pa}]$

$P_{t} \quad$ :全圧 $[\mathrm{Pa}]$

$Q \quad$ :体積流量 $\left[\mathrm{m}^{3} / \mathrm{s}\right]$

$t \quad$ :時間 [s]

$t_{\text {rev }}$ : 翼 1 回転に要する時間 $[\mathrm{s}]$

$t^{*} \quad$ :無次元時間 $\left(=t / t_{\text {rev }}\right)$

$u \quad$ :流速 $[\mathrm{m} / \mathrm{s}]$

$u_{t} \quad$ :羽根車出口周速 $[\mathrm{m} / \mathrm{s}]$

$u_{r} \quad:$ 半径方向流速 $[\mathrm{m} / \mathrm{s}]$

$Z \quad$ :動翼枚数

$\beta \quad$ :流入角 $[\mathrm{deg}]$

$\mu \quad$ :分子粘性係数 $[\mathrm{Pa} \cdot \mathrm{s}]$

$\rho \quad$ : 密度 $\left[\mathrm{kg} / \mathrm{m}^{3}\right]$

$\phi \quad$ :流量係数 $\left(=Q / \pi^{2} D_{2}{ }^{2} B_{2} N\right)$

$\psi$ :圧力係数 $\left(=2 P_{t} / \rho \pi^{2} D_{2}{ }^{2} N^{2}\right)$

添字

1 :羽根車入口 


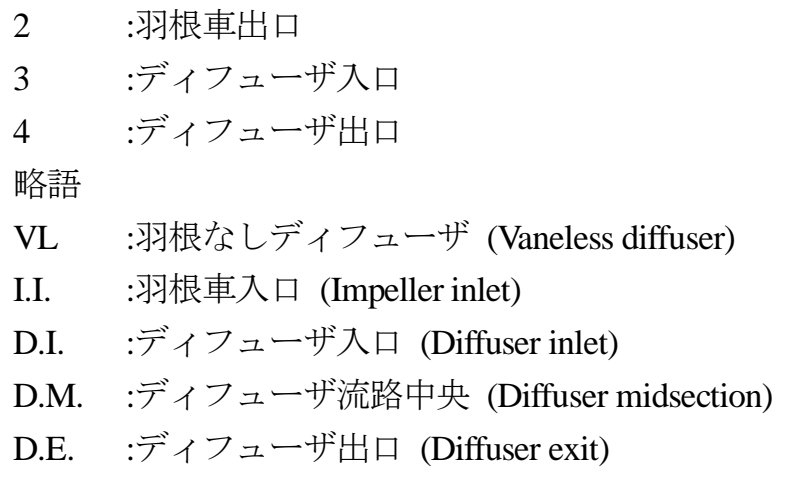

\section{3. 実験装置および実験方法}

\section{$3 \cdot 1$ 実験装置}

供試圧縮機は舶用ディーゼルエンジンに用いられる過給機用遠心圧縮機を過渡現象試験用に改造したもので, 無響室内に設置され $45 \mathrm{~kW}$ の三相誘導電動機により駆動される。供試圧縮機の羽根車およびディフューザの仕様 を表 1 に示す．供試圧縮機の回転数 $6000 \mathrm{~min}^{-1}$ における質量流量および圧力比はそれぞれ $1.64 \mathrm{~kg} / \mathrm{s}, 1.1$ であり， 供試羽根車はインデューサを有する長羽根 7 枚, 短羽根 7 枚から構成される開放型羽根車, ディフューザには羽 根なしディフューザ(VL)を採用した。ディフューザ流路幅は $B_{4}=19.55 \mathrm{~mm}$ である.

Table 1 Design performance of tested centrifugal compressor and dimensions of impeller and diffuser.

\begin{tabular}{ll|ll}
\hline \hline \multicolumn{3}{c}{ Tested Centrifugal Compressor } \\
\hline Rotational Speed & $N$ & 6000 & $\mathrm{~min}^{-1}$ \\
Mass Flow Rate (design point) & $G$ & 1.64 & $\mathrm{~kg} / \mathrm{s}$ \\
Pressure Ratio (design point) & $p_{5} / p_{0}$ & 1.1 & \\
\hline \hline \multicolumn{3}{c}{ Impeller } \\
\hline Number of Blades & $Z$ & 14 & \\
$\quad$ (Main + Splitter) & $D_{1}$ & 248 & \multicolumn{2}{c}{$(7+7)$} \\
Inlet Diameter & $D_{2}$ & 328 & $\mathrm{~mm}$ \\
Outlet Diameter & $B_{2}$ & $26.14 \mathrm{~mm}$ \\
Exit Blade Width & &
\end{tabular}

\begin{tabular}{ll|ll}
\hline \hline \multicolumn{4}{c}{ Diffuser } \\
\hline Inlet Diameter & $D_{3}$ & 328 & $\mathrm{~mm}$ \\
Outlet Diameter & $D_{4}$ & 559 & $\mathrm{~mm}$ \\
Diffuser Width & $B_{4}$ & $19.55 \mathrm{~mm}$ \\
\hline
\end{tabular}

\section{$3 \cdot 2$ 実験方法}

供試圧縮機の性能試験は，JIS 規格 B8340に準拠して行い，圧縮機出口静圧は，渦形室出口直後に設置された 差圧発信器によって, 体積流量は全長 $17 \mathrm{~m}$ の吐出管出口に設置されたバタフライ弁によって制御し, オリフィス 流量計の差圧から算出した。圧縮機内部に発生する非定常現象を調査するために, ディフューザ流路中央におい て周方向に圧力変動計測, およびディフューザ流路内での周方向・子午面方向に流速の非定常計測を実施した. 図 1 に高感度圧力センサ(Kulite XCQ-062, LQ-062)およびスプリット型熱線流速プローブ(DANTEC 55R57)の設置 位置を示す．圧力センサの設置位置は，ディフューザ流路中央(D.M.)の周方向 15 箇所である．また，熱線プロー ブを用いた流速測定では，ブリッジ回路に DANTEC 社製 Streamline システムを用い，A/D変換ボードを介してコ ンピュータに出力電圧を記録した。熱戦プローブの設置位置は，ディフューザ入口(D.I.)の周方向 4 点および 150 度の位置でのディフューザ入口(D.I.), ディフューザ流路中央(D.M.), ディフューザ出口(D.E.)の子午面方向 3 点で ある.また測定は，ハブ側からシュラウド側まで 5\%刻みでトラバース計測を行った. 取得した圧力および流速 の非定常データは, それぞれ FFT アナライザ(小野測器, DS2000)で処理し, パーソナルコンピュータに記録した. また，ディフューザ側壁上の流れは，二酸化チタンと軽油にオレイン酸により作成した油膜により可視化した. 


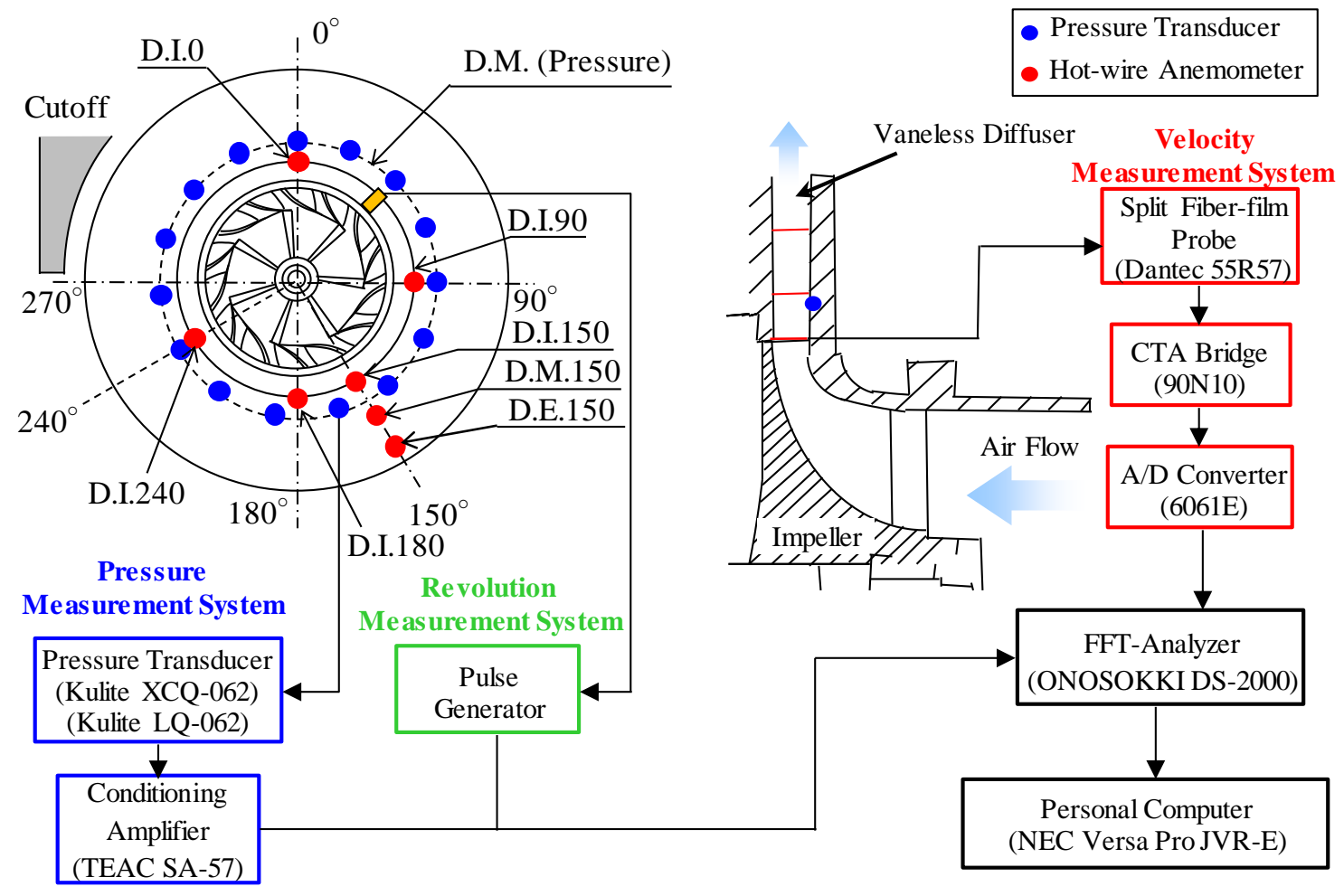

Fig. 1 Experimental apparatus and measuring systems of velocity and pressure fluctuation within diffuser passages.

\section{4. 数值計算手法}

\section{$4 \cdot 1$ 解析スキーム}

圧縮機内部に発生する旋回失速の構造を調查するために, DES（Detached Eddy Simulation）解析を実施した. 支配方程式は連続方程式，3次元圧縮性 Navier-Stokes 方程式，エネルギー保存の式および理想気体の状態方程式 であり，有限体積法により離散化した。対流項には MUSCL 法(van Leer, 1979)により空間 3 次精度とした Roe Scheme (Roe, 1980)を用い，粘性項は中心差分的に評価した。また，時間積分には MFGS 陰解法(Shima, 1997)を採 用した. 乱流モデルには Strelets らが提案した SST k- $\omega$ (Menter, 1994)ベースの SST-DES(Strelets, 2001)を使用した. この DES 解析では，局所的な乱流の渦スケールと格子幅の大小関係に応じて非定常的に RANS/LES 領域を自動 的に切り替えることが可能である. 本研究において，解析領域全体で壁面付近は RANS，主流部はLES 領域とし て良好に RANS/LES 領域の切り替わりが実行されていることを確認済みである(Fujisawa and Ohta, 2017). DES 定 数 $C_{D E S}$ の值は Strelets らが提案した值を用いており, $C_{D E S k-\omega}=0.78$ と $C_{D E S k-\varepsilon}=0.61$ を SST k- $\omega$ モデルのブレンディ ング関数 $F_{1}$ と組み合わせて $C_{D E S}$ を求めた. 動翼回転数は実験と同じ $6000 \mathrm{~min}^{-1}$ とし，相対系には慣性力として遠 心力およびコリオリ力を考慮した. また, 非定常解析における時間刻みを $2 \times 10^{-4} t_{\text {rev }}$ に設定した. 定常解析では, 収束加速法として局所時間刻み法を用いた。

\section{$4 \cdot 2$ 解析格子と境界条件}

解析格子の概略図を図 2 に示寸。計算領域は，相対系で取り扱う羽根車領域，絶対系で取り扱うディフューザ 領域, そして渦型室領域の 3 領域である. 格子点数は翼端隙間を含んだ羽根車領域では約 3200 万点, ディフュー ザ領域は約 1100 万点，渦型室領域は約 2200 万点であり，総格子点数は約 6500 万点である. 格子点数は圧縮機性 能が変わらなくなるまで充填しており, 羽根付ディフューザに発生する旋回失速を解像した過去の解析(Fujisawa and Ohta, 2017)を参考にし，格子密度を決定した．壁面上の最小格子幅は，壁座標 $\mathrm{y}^{+}$が 1 以下を満たすように十 分小さく設定した. 子午面方向のアスペクト比は最大でも 2.5 以内に収まっており, 子午面方向の格子解像度も 
十分である．また，羽根車上流の入口管路長は羽根車失速を再現するには短いが，圧縮機性能や失速発生時のデ イフューザ内部流れは実験結果とよく一致しているため，本報告のディフューザ失速の構造調査には十分である と考えている. 次の段階の調査として, 羽根車上流の入口管路長を伸ばした解析を実施し, 羽根車失速の再現を 行いたい. 羽根車失速の発生の予測と羽根車失速とディフューザ失速の干涉やその構造の調査は，次報を待たな ければならない，解析結果の詳細については次章以降にて述べる。

境界条件として，入口境界には大気圧からの等エントロピおよび等エンタルピを仮定し，大気圧，標準温度を 全圧・全温度として固定した，出口境界には，質量流量固定条件を付与した．また，非定常解析では羽根車領域 とディフューザ領域の接合面にはスライディングメッシュを用いた 1 次元線形近似により各保存量を補間した. 一方，定常解析では，動静翼境界に Mixing Plane を採用した，壁面境界においては，流速に粘着条件を課し，密 度, 圧力にはノイマン条件を課した。
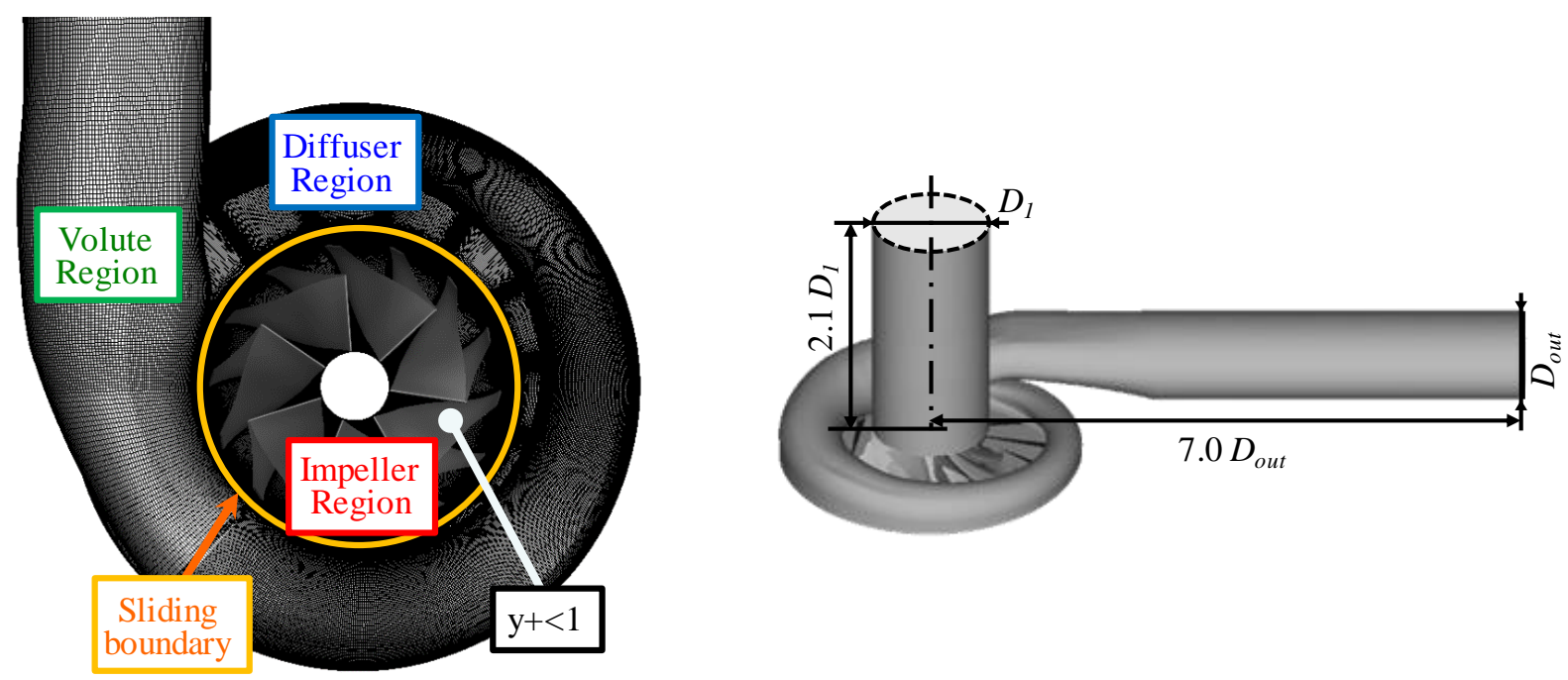

Fig. 2 Overview of computational region and grid used in numerical simulation. The computational region includes impeller, diffuser and volute regions. Total grid number is about 65.0 million.

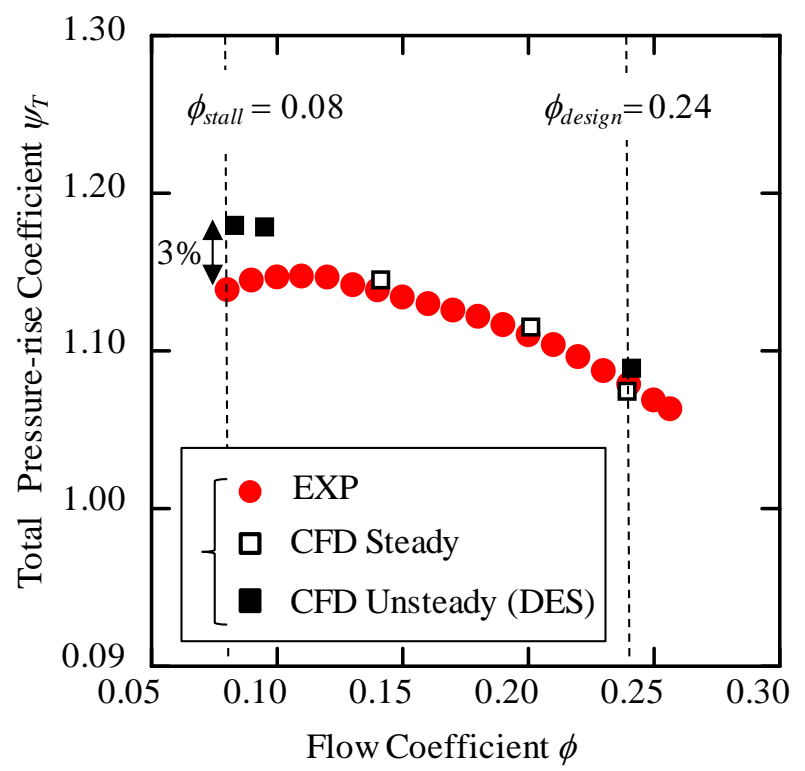

Fig. 3 Characteristics curves of tested centrifugal compressor obtained by experiment and numerical simulations. The design flow coefficient is $\phi=0.24$ and stall flow coefficient is $\phi=0.08$. 


\section{5. 圧縮機の性能と失速特性}

\section{$5 \cdot 1$ 圧縮機性能と基本特性}

実験および数值解析結果より得られた圧縮機性能を図 3 に示す. 流量係数 $\phi=0.24$ は $6000 \mathrm{~min}^{-1}$ 運転時における 供試圧縮機の最高効率点 $\left(\phi_{\text {design }}\right)$ であり， $\phi=0.08$ は供試圧縮機においてディフューザ失速が発生する点 $\left(\phi_{\text {stall }}\right)$ であ る. 図 3 より，定常および非定常解析結果と実験結果はおおよそ一致している．非定常解析の結果は実験結果と 比べ，失速点近傍において圧縮機性能を過大評価しているが，相対誤差は最大でも $3 \%$

図 4 にディフューザ流路中央シュラウド壁面における圧力分布を示す．左図が数值解析結果，右図が試験によ る結果である．図 4 より設計点および失速点ともに解析結果は試験結果と良い一致を示していることがわかる. また, 失速点では設計点と比較して 0 度から 60 度にかけて急激に圧力が上昇しており周方向の強い逆圧力勾配が 生じている.また，図 5 に油膜法および限界流線により可視化した失速点 $\phi=0.08$ でのハブ・シュラウド壁面近 傍の流線を示す。眓 5 より，解析結果により得られた限界流線は油膜法による結果と定性的に良い一致を示して いる. また, ハブ・シュラウド壁面ともに 45 度付近から流線が羽根車入口側へと逆流している様子が確認できる. これは，図 4 に示したように 0 度から 60 度にかけて生じる周方向の強い逆圧力勾配が要因であると考えられる.
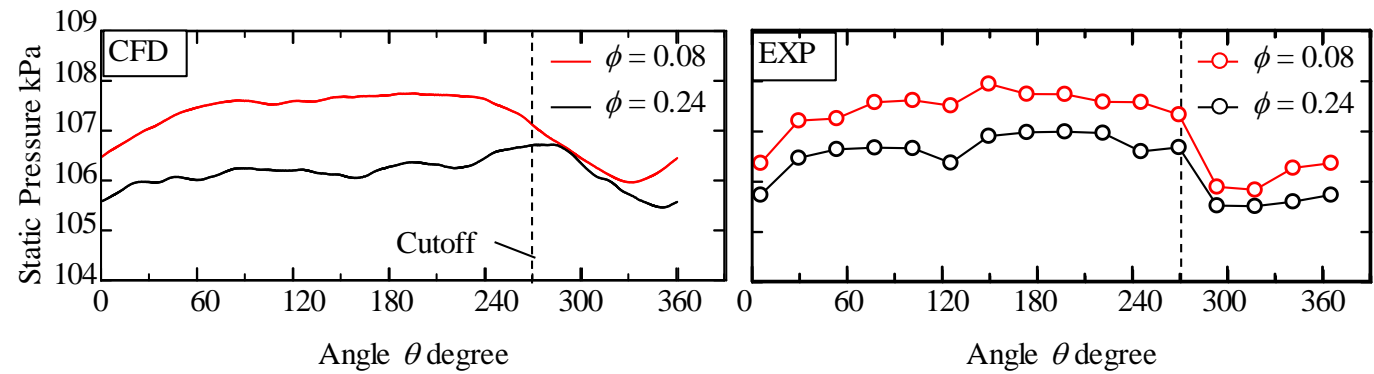

Fig. 4 Circumferential static pressure distributions at $\phi=0.24$ and $\phi=0.08$ obtained from experiment and numerical simulations. From $0^{\circ}$ to the cutoff, the static pressure at $\phi=0.08$ was higher than that of $\phi=0.24$. The magnitude of circumferential adverse pressure gradient was strong near $0^{\circ}$ for $\phi=0.08$
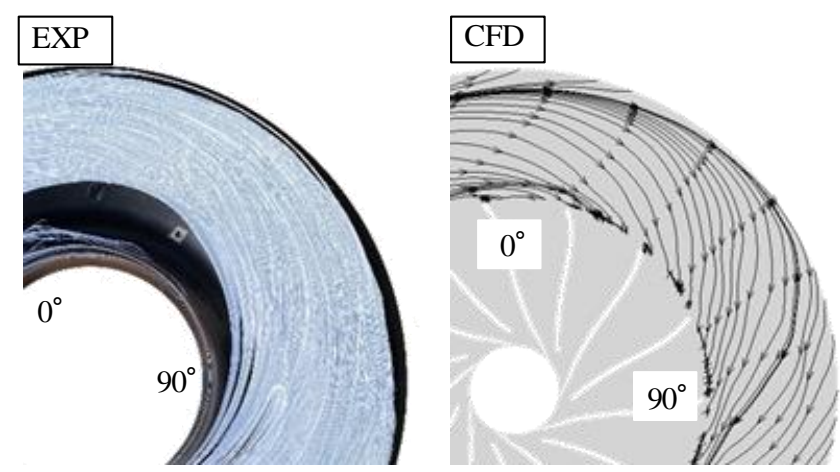

(i) Shroud wall
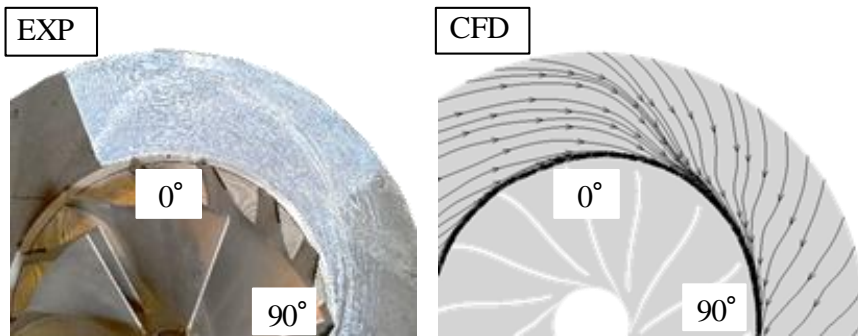

(ii) Hub wall

Fig. 5 Time-averaged limiting streamlines on shroud and hub wall obtained by measurement and CFD analysis at $\phi=$ 0.08. At the experiments, the limiting streamlines were visualized by using an oil film method. The limiting hub and shroud wall streamlines were bent at around $45^{\circ}$ where a small backflow region generated. 


\section{$5 \cdot 2$ 供試圧縮機の失速特性}

供試圧縮機に生じる旋回失速の特性を調査するため，失速点である $\phi=0.08$ にて実験と数值解析を行った．実 験によって得られたディフューザ入口部における流速変動の周波数解析結果を図 6 に示す. 羽根車失速による 58 $\mathrm{Hz}$ 付近の変動のほかに, ディフューザ失速による $25-30 \mathrm{~Hz}$ 帯でのバンド帯での強い変動が確認された. ディフュ 一ザ失速は，周方向位置によってその変動の大きさは異なり，舌部近傍である 240 度において最も強くなる.さ らに，90 度では Hub 側に変動が集中しているが，180 度および 240 度では Shroud 側にも同程度の変動が現れて いることがわかる. また， $\phi=0.08$ では，羽根車失速とディフューザ失速は独立して旋回しており，互いに大き く影響を及ぼしてはいないと考えられる。 これは，過去の調査(Fujisawa and Ohta, 2017)においても，羽根付ディ フューザ設置時に，同様に羽根車失速とディフューザ失速が独立して旋回していたためである. 本解析では入口 管路長が短いために羽根車失速が再現できていないものの, 羽根車吐出流の分布は試験と良く一致していること を確認しており,ディフューザ失速に強く影響を及ぼす羽根車出口の流れが予測できていると考えられる.また， 図 4, 5 で示したようにディフューザ内部の圧力や内部流れ場が試験と良く一致していることからも, 羽根車失速 の影響はディフューザ内部にあまり影響を与えていないことが考えられる．以上より、本解析において羽根なし ディフューザ内部で旋回するディフューザ失速の構造を調査することに問題はない．次に，数值解析より得られ たディフューザ出口部における質量流量変動の結果を図 7 に示す. 数值解析においても周方向に低速で伝播する 低流量域(赤色の領域)が確認され，その旋回速度は羽根車回転数(100Hz)の $25 \%$ 程度であった. 変動の大きさは周 方向で異なり，周方向 45 度付近から変動が強くなり，舌部直前(270 度)まで強い変動が維持されている.また， 舌部通過後は減衰していることが確認できる. 以上より，数值解析においても試験と同様にディフューザ失速の 発生が確認され，その特性も試験と良く一致することがわかった. 次章では，ディフューザ失速の非定常挙動と 旋回機構とに焦点を当て, 数值解析より得られた失速セル周りの非定常内部流れ場を詳細に調查した結果につい て報告する.
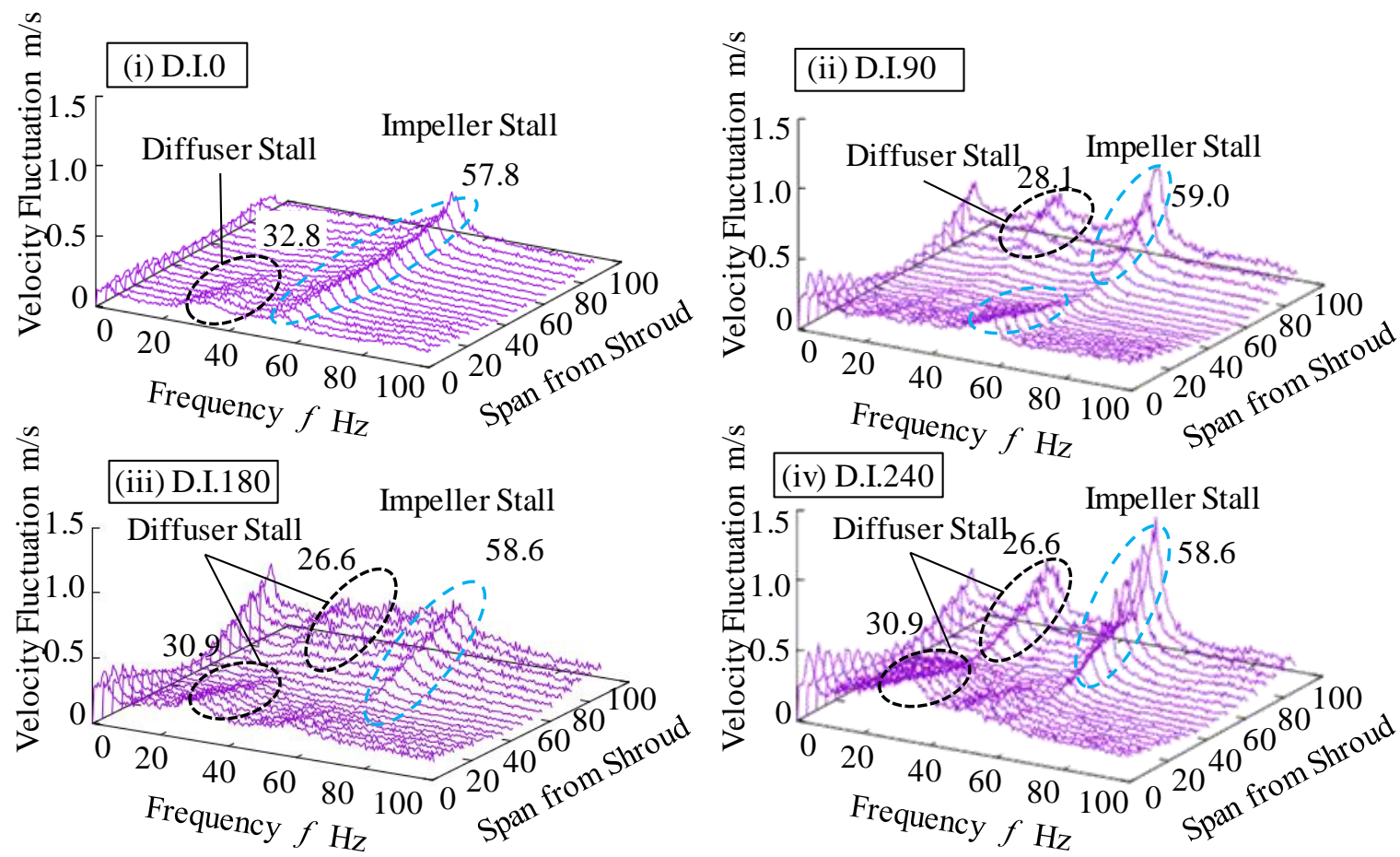

Fig. 6 Fast Fourier transformation (FFT) spatial distribution of velocity fluctuations at diffuser inlet in the spanwise direction at $\phi=0.08$. The unsteady phenomena at around $58 \mathrm{~Hz}$ were caused by a rotating stall within the impeller passages. On the other hand, the lower frequency fluctuation at around $25-30 \mathrm{~Hz}$ was caused by a rotating stall within the vaneless diffuser. Focusing on the diffuser stall, its characteristics varied depending on the circumferential position. 


\section{6. ディフューザ失速の非定常挙動と構造}

\section{$6 \cdot 1$ ディフューザ失速の非定常挙動}

ディフューザ失速の非定常挙動を調査するために, ディフューザ内部流れの半径方向流速の変動を可視化した. 図 8 に数值解析より得られたディフューザ内部の半径方向流速変動の時間変化を示す. 白破線で示す半径方向流 速変動が負となる領域が逆流域に対応し，これは失速セルにあたる。また，各時間は羽根車 1 周に要する時間を 基底とした無次元時間であり，各位置における時間平均值からの差異を変動值としている。図 8 より， $t^{*}=0.94$ において 45 度付近から見られる白の破線で囲まれた逆流領域が初生し, 時間経過とともに舌部に向かって半径方 向および周方向に拡大しながら旋回している様子が確認される．また， $t^{*}=1.16$ 以降の失速セルが 90 度を過ぎた 後は, ディフューザ出口側からの逆流が増大している. その後, $t^{*}=3.60$ 以降の失速セルが舌部を通過して以降,

Mass Flow Fluctuation kg/s

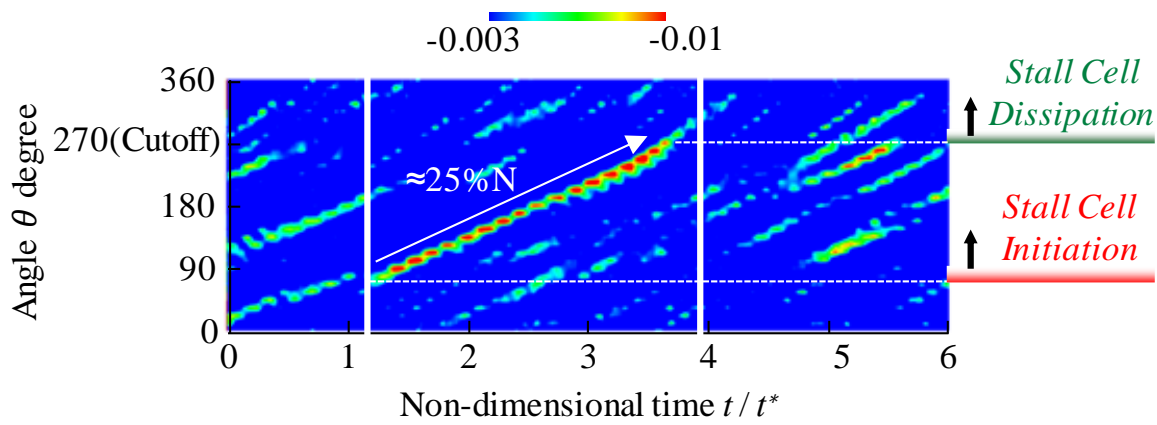

Fig. 7 The mass flow fluctuations at the diffuser exit obtained from CFD analysis. The large magnitudes area of velocity fluctuations indicated low mass flow regions and this rotational speed was about $25 \%$ of the impeller rotation speed. This low mass flow region appeared at $90^{\circ}$ and disappeared after passing the cutoff. Both experiment and CFD analysis indicated that the diffuser rotating stall initiated at $90^{\circ}$ and developed further as the diffuser stall cell approached the cutoff. After passing the cutoff, the diffuser rotating stall was attenuated.

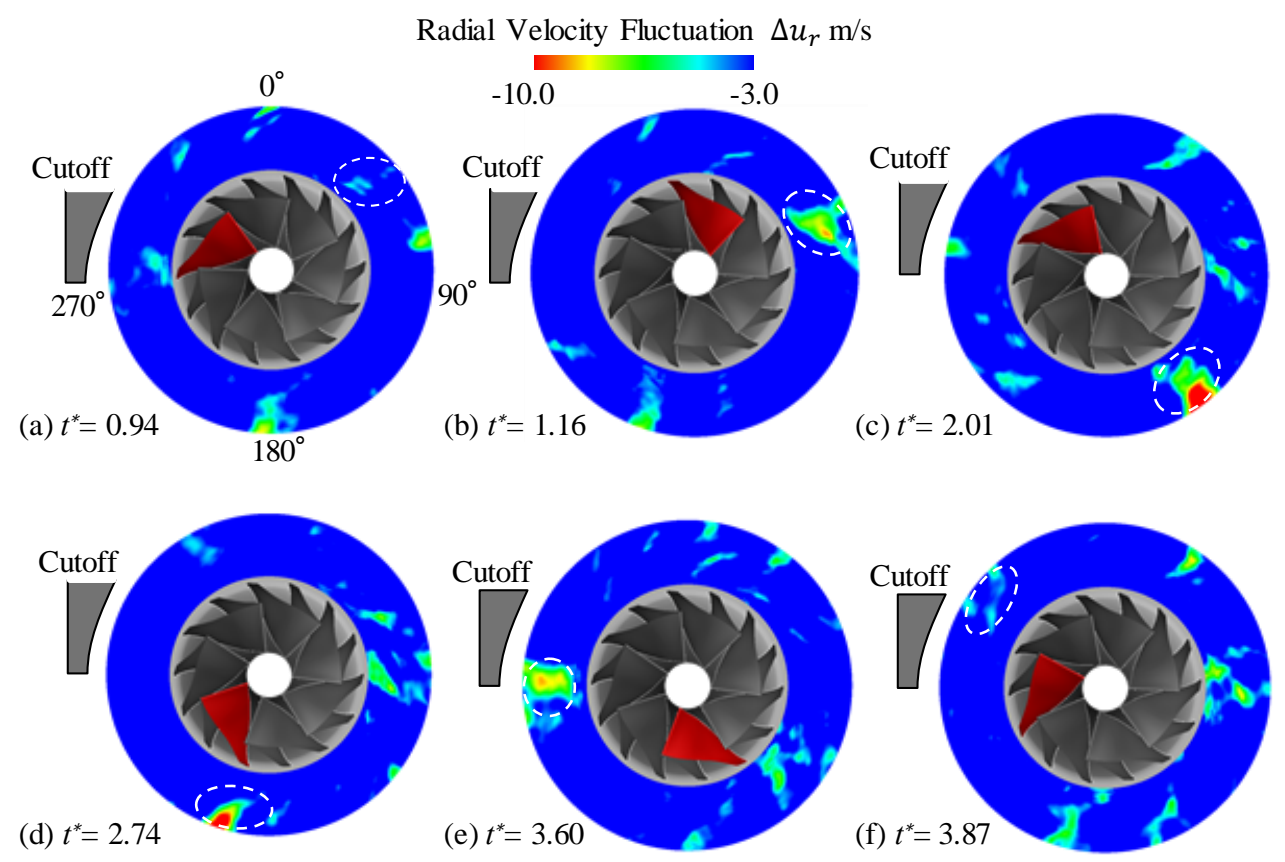

Fig. 8 Distributions of radial velocity fluctuation within the diffuser passage obtained by CFD analysis. The region indicated by the white dashed circle is the diffuser stall cell that induced the largest mass flow fluctuations. At $t^{*}=0.94$, the region with the large velocity fluctuations was first generated at around $45^{\circ}$. Then, the large fluctuations region was formed at the diffuser exit area. After that, the diffuser stall cell expanded both radially and circumferentially as it approached the cutoff. Finally, the stall cell size reduced after passing the cutoff. 


\section{白破線で示す領域が縮小し，変動の大きさも低下していることがわかる.}

ディフューザ失速が45度付近で初生し，成長していく過程における非定常挙動を調査するために，ディフュー ザ流路から渦型室入口部までの子午面流速分布を図9に示す。4つの領域(I)45-75度，(II)90-135度，(III)180-225度， (IV)300-340度付近を失速セルが通過した時刻におけるディフューザ内部流れを可視化した. 図9には，子午面流 速分布とともに，半径方向流速 $u_{r}=-10 \mathrm{~m} / \mathrm{s}$ の等值面を付記している. また，(a)の青破線がHub壁面境界層の剥離 線に，(b)の赤破線がShroud壁面境界層の剥離線の位置に対応している. 図9(I)から，45度付近よりディフューザ 流路入口部から中間部にかけてHub壁面に小規模な壁面境界層剥離が発生していることがわかる. これは図4で示 したように，周方向の強い逆圧力勾配が生じているためである. 次に，図9(II)では，(I)で発生した境界層剥離が 集積・拡大し，90度付近からHub，Shroud両壁面に交互の大規模な剥離領域が形成されている．また，ディフュ

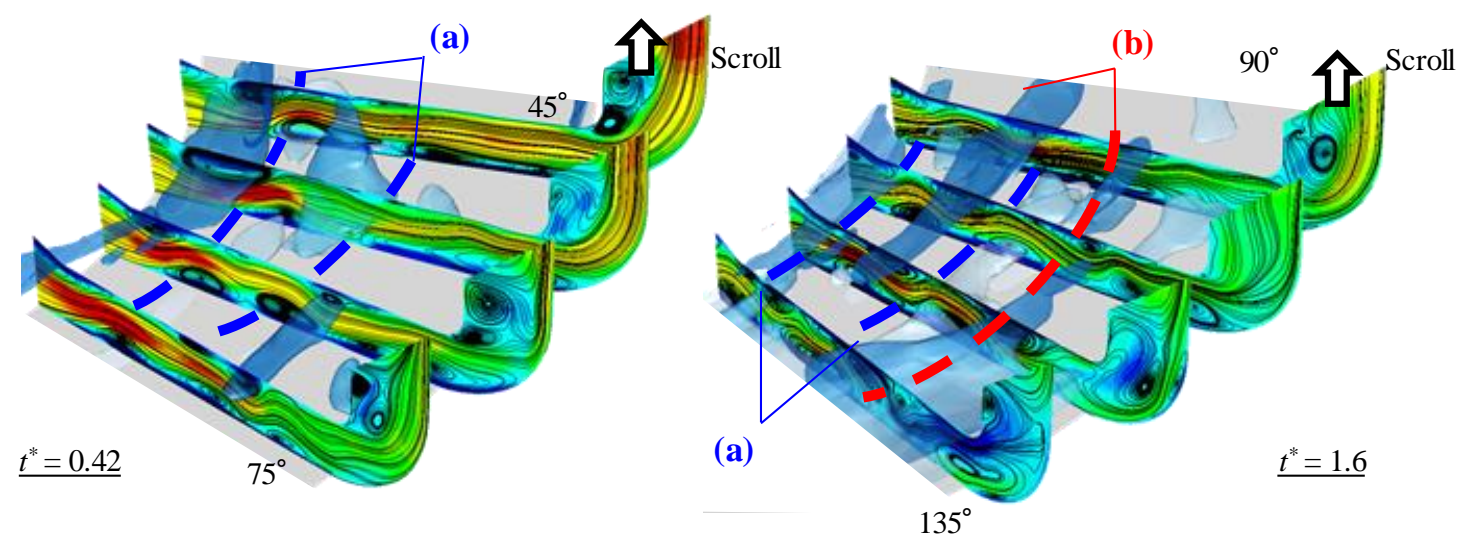

(I) $45-75 \mathrm{deg}$

(II) $90-135 \mathrm{deg}$
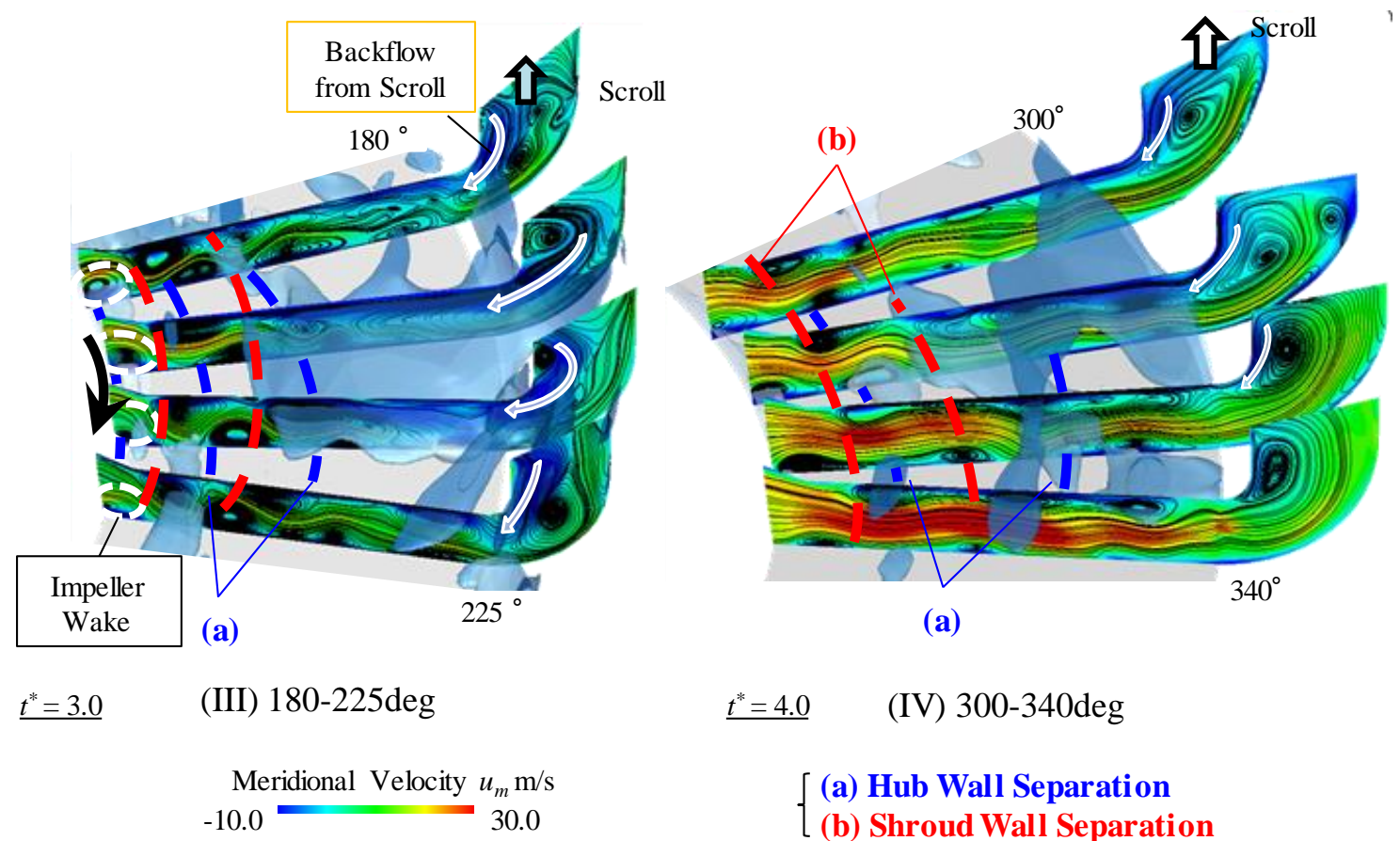

(a) Hub Wall Separation

(b) Shroud Wall Separation

Fig. 9 Meridional velocity distribution around the stall cell and the iso-surface of $u_{r}=-10 \mathrm{~m} / \mathrm{s}$. The blue dashed line represents the hub wall separation and the red one indicated the shroud wall separation. The hub wall boundary layer separation initiated at around $45^{\circ}$. Then, this hub wall separation induced the next shroud wall separation because of a spanwise pressure gradient. The low velocity region within vaneless diffuser developed due to the boundary layer separations occurring on the shroud and hub wall by turns. Finally, the low velocity region formed the entire diffuser passage span blockage. After passing cutoff, the size of boundary layer separations occurring on the shroud and hub wall was decreased and the reverse flow from the casing was diminished. 
一ザ出口と渦型室入口の接続部にあたる曲がり部のShroud側に，低速領域が形成され始めている．次に図9(III)の 180度付近においては，Hub，Shroud壁面交互の境界層剥離が更に拡大し，スクロール側からの逆流がディフュー ザ内部まで伸びていることがわかる，そして，舌部の後方にあたる図9(IV)の300度付近では，境界層剥離および 渦型室側からの逆流の規模は, 図9(III) と比べると縮小している。 これは舌部通過後にディフューザ出口圧が低減 し羽根車吐出流量が増加することおよび，渦型室の流路断面積の減少による縮流の影響によって，失速セルが縮 小し渦型室からの逆流が抑制されるためである。 つまり, ディフューザ失速セルはHub壁面の境界層剥離が集積 することで初生し，ディフューザのHub，Shroud壁面交互の境界層剥離および渦型室からの逆流を伴いながら拡 大・旋回すると考えられる.

図9より旋回失速セルの構造および規模は周方向位置によって異なる様相を呈しており, 同様に子午面方向にも 複雑な特性を持つことがわかった。 そこで，試験でのディフューザ失速の子午面方向の特性を調査するために， 周方向位置(150度)におけるディフューザ入口部(D.I.)，流路中央部(D.M.)，出口部(D.E.)の子午面3点にて流速変動 の周波数解析結果を図10に示す. ディフューザ入口部ではHub側に集中していたディフューザ失速による変動は, 流路中央部においてShroud側に移り, 出口部では変動を弱めつつMidスパン全体に広がっている．以上より，図 9(II)の結果より失速セルがHub, Shroud壁面交互の境界層剥離により構成されるように，試験結果からも失速セル の特性が子午面方向に変化することが確認された。
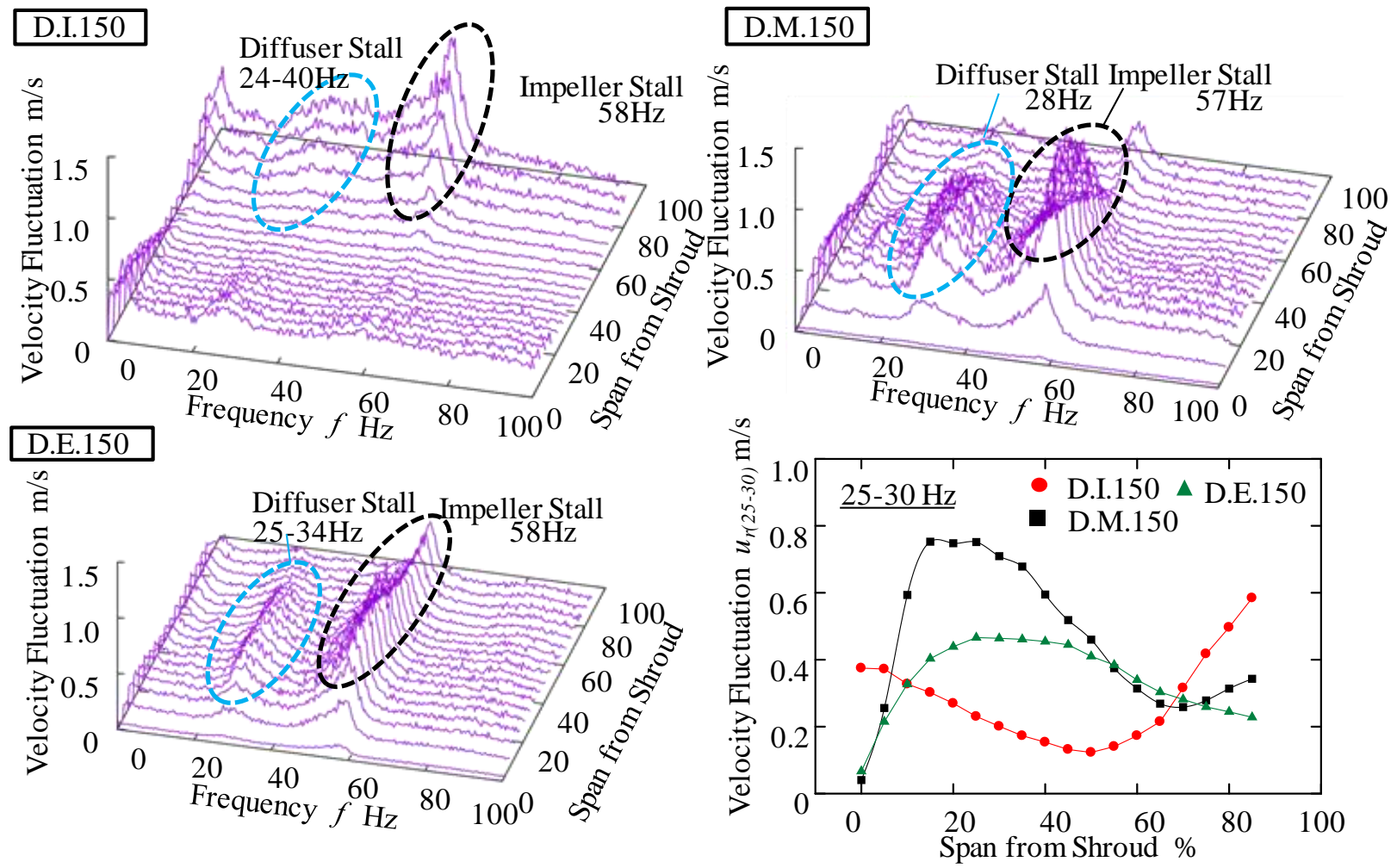

Fig. 10 Radial velocity fluctuation of impeller discharge flow was measured at the meridional direction. The diffuser stall fluctuations were observed near hub side at D.I.150. On the other hand, the region with large magnitudes of the diffuser stall was shifted to the shroud side at D.M.150 and D.E.150. It is because the diffuser stall was consisted of the boundary layer separations occurring on the shroud and hub wall by turns. Therefore, the boundary layer separations occurring on the shroud and hub wall were considered as the key factors contributing to the diffuser stall generation by both experimental and CFD results.

\section{$6 \cdot 2$ ディフューザ失速の旋回機構}

ディフューザ失速セルの旋回機構を明らかにするため, 図11に180度位置に存在する失速セル周りのスパン方向 に平均化を施した静圧変動分布を示す，また，同位置における流れ角変動分布を示寸．図11には，半径方向流速 $u_{r}=-10 \mathrm{~m} / \mathrm{s}$ の等值面を付記している. 図11左図より, 失速セルの前縁側では低圧領域が，後縁側では高圧領域が 


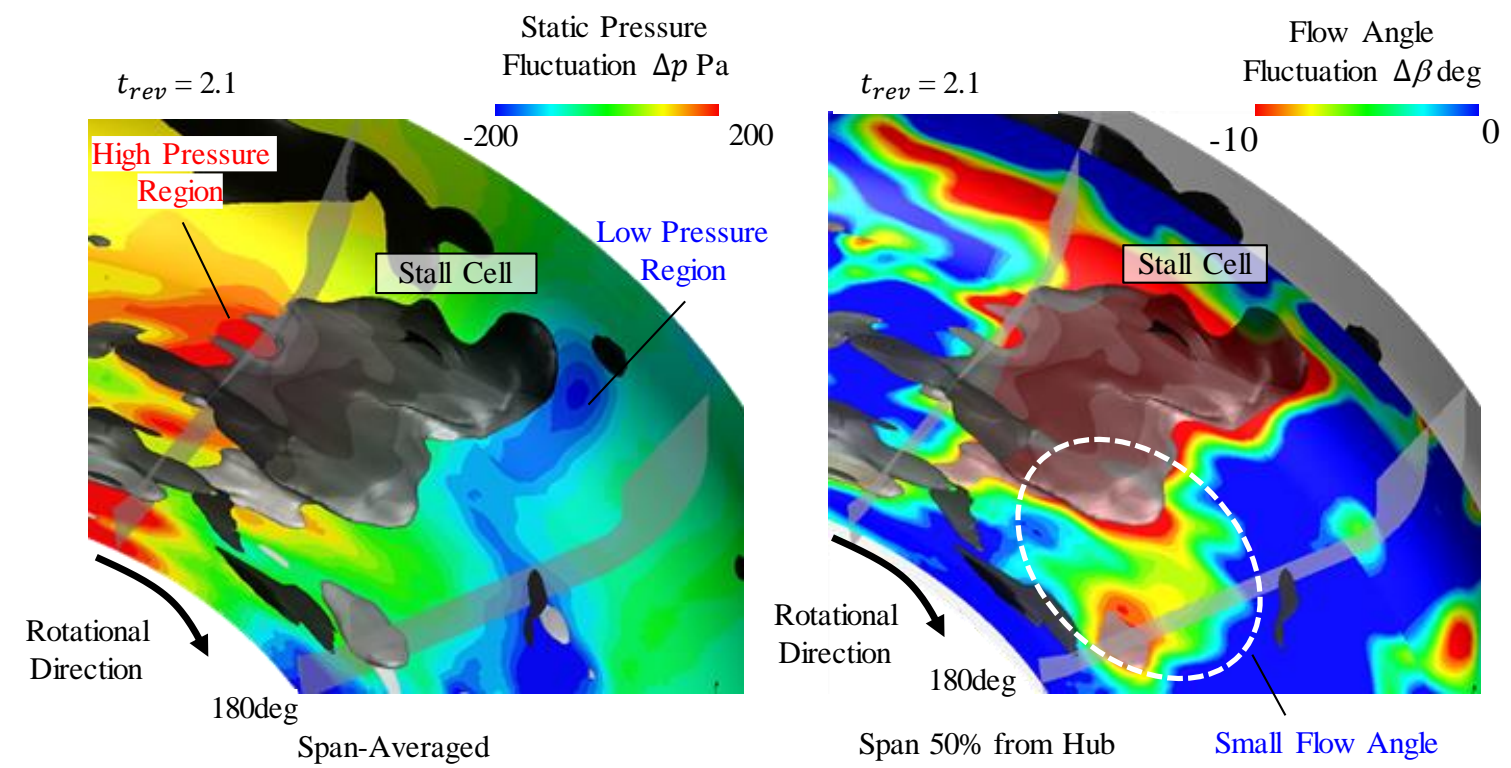

Fig. 11 Distributions of span averaged pressure fluctuations and flow angle fluctuations around the stall cell. The static pressure was increased behind of the stall cell as the main flow collided with the low velocity area. The static pressure was decreased ahead of the rotating stall because of merging the impeller discharge flow and the reverse flow from the casing. In addition, the flow angle was decreased by merging the impeller discharge flow and the reverse flow from the casing.

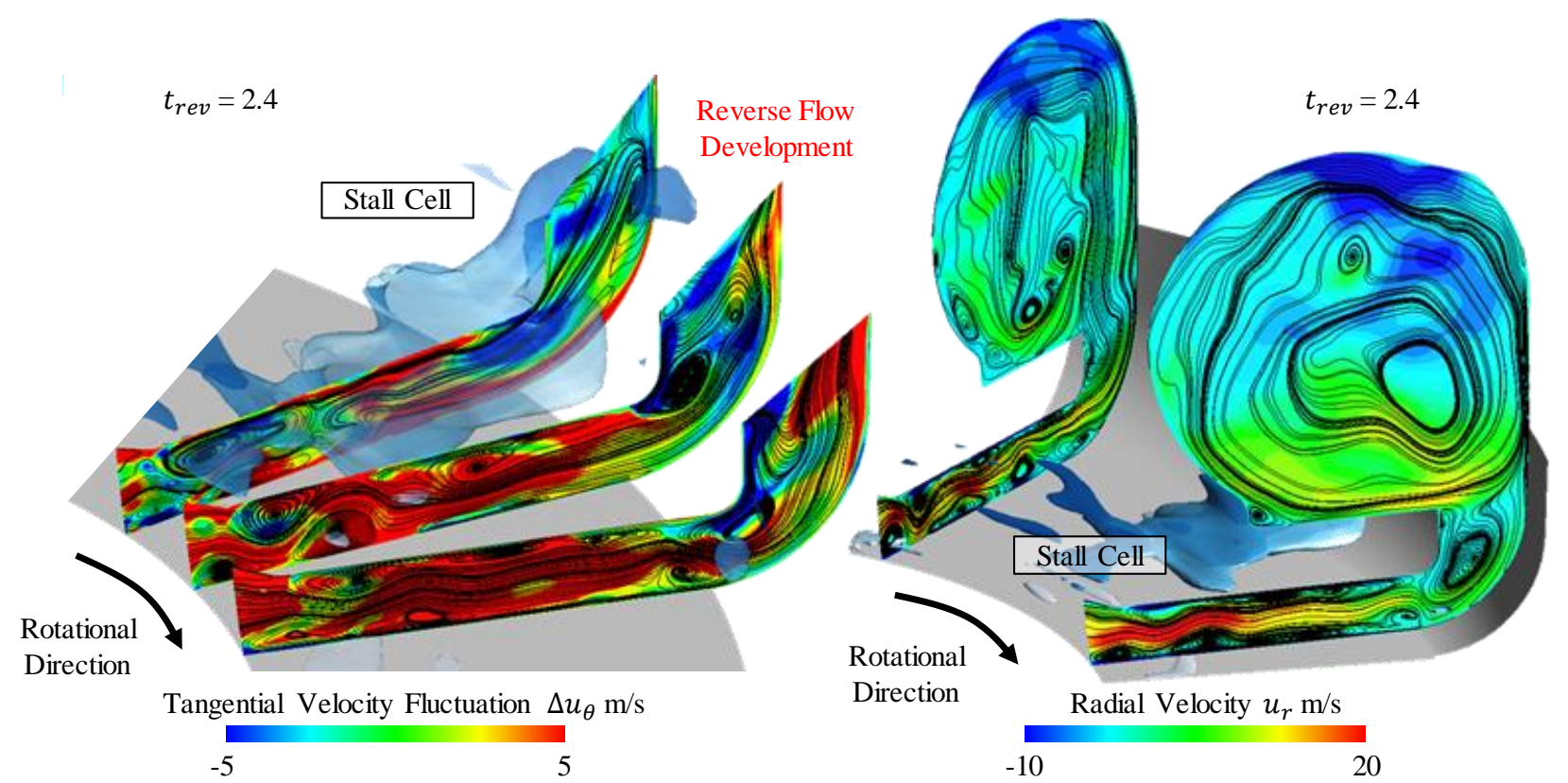

Fig. 12 Distributions of tangential velocity fluctuations and radial velocity within diffuser and casing passages around the stall cell. The reverse flow was developed by the evolution of separation vortex at diffuser exit because of the low-pressure area ahead of the stall cell. The boundary layer separations started occurring on the shroud and hub wall ahead of the stall cell due to the small flow angle.

形成されることが確認された．高圧領域は失速セルを構成する低速領域に主流が衝突することにより生じる，一 方，低圧領域は失速セルを避け失速セルの前縁側へと流れた羽根車吐出流と渦型室からの逆流が合流することに よる周方向流速の加速の影響によるものである。このような失速セル周辺の流れ場の傾向は，ディフューザ流路 を解析対象とした簡易な2次元の数值解析においても確認されている(辻本他，1994). ただし，本解析は渦型室や 羽根車領域を考慮した3次元解析であり, 先述したように失速セル周りの流れにはディフューザ内部流れだけでな く, 羽根車吐出流や渦型室からの逆流が強く影響を与えている，さらに，図11右図より羽根車吐出流と渦型室か 
Fujisawa, Miida, Tajima and Ohta, Transactions of the JSME (in Japanese), Vol.87, No.894 (2021)

らの逆流が合流することによる周方向流速が加速した失速セルの前縁側では，流れ角が小さくなっていることが わかる。

失速セル周辺の圧力場や流れ角が失速の旋回機構に与える影響を調查するため, 失速セル周辺の周方向流速変 動分布を図12左図に，半径方向流速分布を図12右図に示す．図12には，半径方向流速 $u_{r}=-10 \mathrm{~m} / \mathrm{s}$ 等值面を付記 している. 図12左図より，ディフューザ流路間では失速セルの前縁側からHub, Shroud壁面交互の境界層剥離が初 生し始め, 失速セルに近づくにつれその規模が大きくなっていることがわかる.これは，図11に示したように失 速セルの前縁側では流れ角が小さくなるために, 壁面での剥離が誘起されや寸くなったためである. また，ディ フューザ出口部Shroud側での剥離渦も失速セルに近づくにつれ大きくなり，セルの中心では大きな逆流領域へと 成長していることがわかる，これは，図11に示した低圧領域に渦型室の流れが引き寄せされているためであると 考えられる.さらに, 図12右図より, 低圧領域が存在する失速セルの前縁側では, 後縁側と比較して渦型室入口 曲がり部での剥離渦の規模が大きくなっていることがわかる.

以上の結果を踏まえて，失速セルの内部構造と旋回機構を図13にまとめた. ディフューザ流路間および渦型室 内部の低速領域の等值面を可視化しており, 境界層剥離に起因寸るものを青色, 渦型室からの逆流に起因するも のを赤色で示す，図13に示すように，ディフューザ失速セルはHub，Shroud壁面交互の境界層剥離と渦型室から の逆流に起因するディフューザ出口部の低速領域で構成される. また, 失速セル周辺では, 失速セルの後縁側に て低速領域に主流が衝突することにより生じる高圧領域，失速セルの前縁側での周方向流速の加速の影響による 低圧領域が形成される. 低圧領域に渦型室の流れが引き寄せされるために, 渦型室入口では逆流領域が失速セル に近づくにつれ成長する，また，羽根車吐出流と渦型室からの逆流が合流することにより，流れ角が小さくなる ことで, 失速セルの前緑側ではHub, Shroud壁面交互の境界層剥離が初生する.つまり, 失速セルはHub, Shroud壁 面交互の境界層剥離と渦型室からの逆流が周方向に初生・成長していくことで, 低速領域を形成しながら旋回し ていくと考えられる。

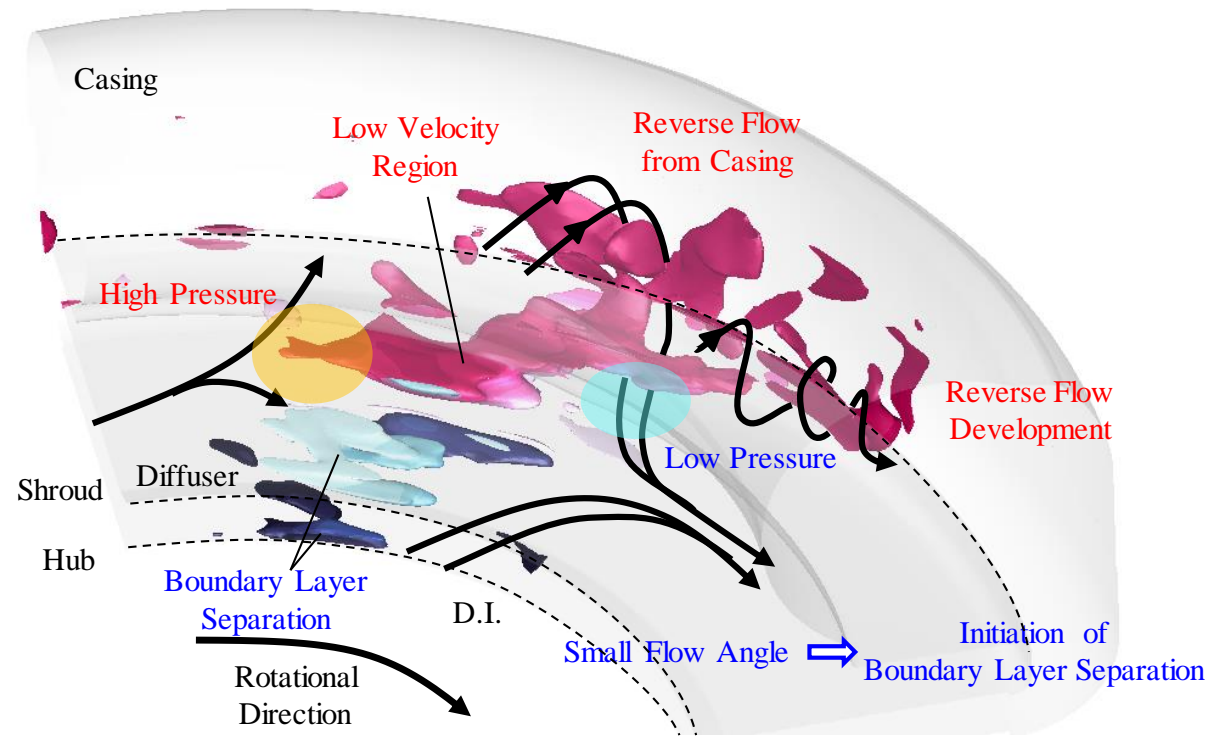

Fig. 13 Sketch and rotating mechanism of diffuser stall cell. The static pressure was decreased ahead of the rotating stall because of merging the impeller discharge flow and the reverse flow from the casing. In addition, the flow angle was decreased by merging the impeller discharge flow and the reverse flow from the casing. Therefore, the boundary layer separations started occurring on the shroud and hub wall ahead of the stall cell. The rotating mechanism of diffuser stall was induced by the reverse flow development and decrease of flow angle ahead of the stall cell. 


\section{7. 結 言}

羽根なしディフューザを有する遠心圧縮機に発生する失速現象の非定常挙動および構造を調査するために, 実 験および数值解析を行った. 得られた知見を以下にまとめる.

(1) 実験および数值解析で, $\phi=0.08$ においてディフューザ失速による $25-30 \mathrm{~Hz}$ 帯の非定常現象が確認された. ディフューザ失速による変動は周方向 45 度付近から強くなり, 舌部直前(270 度)まで強い変動が維持され, 舌部通過後は減衰している.

（2）ディフューザ失速の特性は周方向および子午面方向に異なっている. ディフューザ失速セルは周方向 45 度 付近にて周方向の逆圧力勾配により生じる Hub 壁面の境界層剥離が集積することで初生する. その後, ディ フューザの Hub, Shroud 壁面交互の境界層剥離および渦型室からの逆流を伴いながら拡大・旋回寸ると考え られる. 舌部通過後は, ディフューザ出口圧が低減し羽根車吐出流量が増加することおよび，渦型室の流路 断面積の減少による縮流の影響によって，失速セルは縮小寸る。

（3）失速セルの前縁側では, 周方向流速の加速の影響による低圧領域が形成される. 低圧領域に渦型室の流れが 引き寄せされるために，渦型室入口では逆流領域が失速セルに近づくにつれ成長する. また，羽根車吐出流 と渦型室からの逆流が合流することにより, 流れ角が小さくなることで, 失速セルの前縁側では Hub, Shroud 壁面交互の境界層剥離が初生する。つまり, 失速セルの旋回機構は Hub, Shroud 壁面交互の境界層剥離と 渦型室からの逆流が周方向に初生・成長していくことが主要な要因であると考えられる.

\section{文献}

Bianchini, A., Biliotti, D., Rubino, D. T., Ferrari, L. and Ferrara, G., Experimental analysis of the pressure field inside a vaneless diffuser from rotating stall inception to surge, Transactions of the ASME, Journal of Turbomachinery, Vol. 137(2015), 111007.

Dehner, R. and Selamet, A., Three-dimensional computational fluid dynamics prediction of turbocharger centrifugal compression system instabilities, Transactions of the ASME, Journal of Turbomachinery, Vol.141(2019), 081004.

Fujisawa, N. and Ohta, Y., Transition process from diffuser stall to stage stall in a centrifugal compressor with a vaned diffuser, International Journal of Rotating Machinery, Vol.2017(2017), Article ID 2861257.

Fujisawa, N., Inui, T. and Ohta, Y., Evolution process of diffuser stall in a centrifugal compressor with vaned diffuser, Transactions of the ASME, Journal of Turbomachinery, Vol.141(2019), 041009.

Menter, F. R., Two-equation eddy viscosity turbulence models for engineering applications, AIAA Journal, Vol.32 (1994), pp.269-289.

Ohuchida, S., Kawakubo, T. and Tamaki, H., Experimental study of rotating stall in vaneless diffuser of a centrifugal compressor, Proceedings of ASME Turbo Expo 2013, GT2013-95468 (2013).

Roe, P. L., The use of the Riemann problem in finite difference schemes, Lecture Notes in Physics, Vol.141, Proceedings of the 7th Internal Conference on Numerical Methods in Fluid Dynamics, Springer Verlag (1980).

Senoo, Y., Kinoshita, Y. and Ishida, M., Influence of inlet flow conditions and geometries of centrifugal vaneless diffusers on critical flow angle for reverse flow, Transactions of the ASME, Journal of Turbomachinery Journal of Fluids Engineering, Vol. 99 (1977), pp.104-114.

Senoo, Y. and Kinoshita, Y., Limits of rotating stall and stall in vaneless diffuser of centrifugal compressors, ASME Paper, No.78-FT-19 (1978).

Shima, E., A simple implicit scheme for structured/unstructured CFD, Proceedings of 29th Fluid Dynamics Conference (1997), pp.325-328.

Strelets, M., Detached eddy simulation of massively separated flows, AIAA Paper, 2001-0879 (2001).

辻本良信, 吉田義樹, 森康真, ベーンレスディフューザの旋回失速の二次元非粘性解析に基づく研究(第 1 報, 線形解 析), 日本機械学会論文集 B 編, Vol.60, No.572(1994), pp.1296-1301.

van Leer, B., Towards the ultimate conservative difference scheme V: A second-order sequel to Godunov's method, Journal of 
Computational Physics, Vol.32 (1979), pp.101-136.

Yamada, K., Furukawa, M., Arai, H. and Kanazaki, D., Evolution of reverse flow in a transonic centrifugal compressor at near-surge, Proceedings of ASME Turbo Expo 2017, GT2017-63568 (2017).

\section{References}

Bianchini, A., Biliotti, D., Rubino, D. T., Ferrari, L. and Ferrara, G., Experimental analysis of the pressure field inside a vaneless diffuser from rotating stall inception to surge, Transactions of the ASME, Journal of Turbomachinery, Vol. 137(2015), 111007.

Dehner, R. and Selamet, A., Three-dimensional computational fluid dynamics prediction of turbocharger centrifugal compression system instabilities, Transactions of the ASME, Journal of Turbomachinery, Vol.141(2019), 081004.

Fujisawa, N. and Ohta, Y., Transition process from diffuser stall to stage stall in a centrifugal compressor with a vaned diffuser, International Journal of Rotating Machinery, Vol.2017(2017), Article ID 2861257.

Fujisawa, N., Inui, T. and Ohta, Y., Evolution process of diffuser stall in a centrifugal compressor with vaned diffuser, Transactions of the ASME, Journal of Turbomachinery, Vol.141(2019), 041009.

Menter, F. R., Two-equation eddy viscosity turbulence models for engineering applications, AIAA Journal, Vol.32 (1994), pp.269-289.

Ohuchida, S., Kawakubo, T. and Tamaki, H., Experimental study of rotating stall in vaneless diffuser of a centrifugal compressor, Proceedings of ASME Turbo Expo 2013, GT2013-95468 (2013).

Roe, P. L., The use of the Riemann problem in finite difference schemes, Lecture Notes in Physics, Vol.141, Proceedings of the 7th Internal Conference on Numerical Methods in Fluid Dynamics, Springer Verlag (1980).

Senoo, Y., Kinoshita, Y. and Ishida, M., Influence of inlet flow conditions and geometries of centrifugal vaneless diffusers on critical flow angle for reverse flow, Transactions of the ASME, Journal of Turbomachinery Journal of Fluids Engineering, Vol. 99 (1977), pp.104-114.

Senoo, Y. and Kinoshita, Y., Limits of rotating stall and stall in vaneless diffuser of centrifugal compressors, ASME Paper, No.78-FT-19 (1978).

Shima, E., A simple implicit scheme for structured/unstructured CFD, Proceedings of 29th Fluid Dynamics Conference (1997), pp.325-328.

Strelets, M., Detached eddy simulation of massively separated flows, AIAA Paper, 2001-0879 (2001).

Tsujimoto, Y., Yoshida, Y. and Mori, Y., Vaneless diffuser rotating stall based on two-dimensional inviscid flow analysis $\left(1^{\text {st }}\right.$ Report, Liner Analysis), Transactions of the Japan Society of Mechanical Engineers, Series B, Vol.60, No.572(1994), pp.1296-1301 (in Japanese).

van Leer, B., Towards the ultimate conservative difference scheme V: A second-order sequel to Godunov's method, Journal of Computational Physics, Vol.32 (1979), pp.101-136.

Yamada, K., Furukawa, M., Arai, H. and Kanazaki, D., Evolution of reverse flow in a transonic centrifugal compressor at near-surge, Proceedings of ASME Turbo Expo 2017, GT2017-63568 (2017). 